\title{
On Labour Migration in India: Trends, Causes and Impacts
}

\author{
Tilak Sanyal* and Kingsuk Maity \\ Department of Economics, Shibpur Dinobundhoo College, Howrah, West Bengal, India \\ *Corresponding author: sanyal.tilak@gmail.com
}

\begin{abstract}
The paper considers the issue of labour migration which is very significant for economic development of any nation. It presents in a nutshell the trends and patterns of migration in India, its causes and impacts as discussed in the literature so far. After doing a rigorous survey of the literature we observe that the issue is, in some sense, neglected and its importance is underestimated. Hence, the paper would serve as a useful guide to the future research on this area.
\end{abstract}

JEL Classification: R23, J12, J31, J46, J11.

Keywords: Regional Migration, Marriage, Wage differentials, Informal Labour Markets, Demographic Trends.

Every economy is confronted with certain economic problems. Some of them may be external, while some may be internal. Among all the internal problems, unemployment gains huge importance both in economic theories as well as in terms of policy prescriptions. Every individual wishes to get employed to have a source of more or less steady flow of incomes. Incomes provide purchasing power to individuals and hence they can improve their standard of living. So, if an individual cannot find job in her current location, then she can decide to move out of that place and relocate to some other region in search of employment. This phenomenon is regarded as 'labour migration'. Migration is defined as a move from one migration defining area to another, usually crossing administrative boundaries made during a given migration interval and involving a change of residence ${ }^{1}$. In general, the level of development gap between the economies and also between the regions within an economy induces an individual to migrate from a region where opportunity to find jobs is lower to a region where job finding is easier. Migration can be of two types - internal migration (from one region to another but within the same country) and external

\footnotetext{
${ }^{1}$ The United Nations proposed this definition of migration in 1993.
}

migration or emigration (from one country to another country). In the global scenario, internal migration seems to be more significant than the external migration ${ }^{2}$.

One major reason for which labourers migrate from one region to another region is in search of employment. Even in a situation where an individual is indifferent between the two regions in terms of employment opportunities still there can be an incidence of migration. In that case, the wage difference between the two regions determines the direction of migration. The labourers migrate from a region of lower wage rate to a region of higher wage rate. The continuous migration creates competition among the potential workers which lowers the wage rate. This process continues unless the wage-gap between the two regions is eliminated. Thus labour migration can achieve balance in the wage rates of the two regions. This phenomenon is known as 'convergence' in literature. But in reality whether this type of inter-regional convergence occurs or not is a highly debatable issue. Further, due to competition among the migrants finding

\footnotetext{
${ }^{2}$ The United Nations Development Programme (2009) has estimated that the number of migrants within the borders of countries is about four times the number of migrants.
} 
a job in another region involves an element of uncertainty. In this situation an individual calculates the expected earnings and only when it exceeds the present earning, they decide to migrate.

Moreover, the job-search motive cannot be the sole cause for migration. The extent of migration also depends on other factors like age, sex, level of education, caste, religion and socio-economic status of the migrants. For example, with the development of Bangalore as an information technology (IT) city many IT professionals have migrated from different parts of India to Bangalore. Likewise, we observe that some regions are densely populated by the people belonging to a particular religious community. Sex of the migrant is another vital attribute determining the extent of migration. Male workers migrate mainly to search for employment opportunities. But females migrate mainly on account of marriage. Thus the importance of these factors cannot be ignored.

The extent of labour migration also affects the growth level of a particular region. The classical growth theories have shown that resources in the form of migrants can be used by an economy for its development purpose. The Lewis model of development (1954) proposes that migration of surplus labour from the subsistence sector to the urban manufacturing sector creates surplus in the latter sector. This surplus can be used for capital formation and growth of the economy through reinvestment. Although this result has theoretical implications but the identification of surplus labour in the subsistence sector creates a huge problem. The Harris-Todaro model of development (1970) also suggests migration of labour from rural to urban sectors can achieve growth. In their model, the expected earnings in the urban sector is at least as high as the earning in rural sector is used as a precondition of migration. An interesting implication of these theoretical results is that labour migration can be effectively used for development of the region to which the workers migrate. But if this is true, then it would never lead to convergence of the two regions. The development gap between the two regions would diverge although the wage gap might converge.

The informal production systems are more widely spread across rural and urban spaces. Thus finding a job is easier in informal sectors than in formal sectors. As a result the number of migrants tends to increase in the informal sectors. But, in general, informal sectors do not present a very good environment for work. It might adversely affect the satisfaction level of the migrants. But such problems are likely to be absent in the formal sectors where the participation of skilled and educated workers is high. In other words, the labour market under globalization is placing a higher premium on the skilled migrants. Moreover, in many situations the poor workers migrating from rural to urban areas access employment through a chain of intermediaries. Hence it can lead to exploitation of the poor workers by the intermediaries.

The remittances and savings of the migrants can also be helpful to improve the standard of living of the people of the recipient regions.

Thus cause, nature and extent of labour migration have impacts on the socio-cultural and politicaleconomic environment of the state. With the advent of liberalization, inequalities in the labour market have widened and the nature of the market has changed towards greater informalization and flexibility. At the same time growth in India and the demand for certain types of labour follow the needs for capital, both national and global. An implication of this need is the surge in demand for highly skilled workers, on the one hand, and a mass of low skilled, low paid, easily controlled and highly flexible workforce, on the other hand. This increase in demand cannot be met by local labour and hence, increased worker mobility is required. But the mobile workforce acquires highly dualistic characteristics. On the one hand, migration of workers in the upper segment of the workforce has increased. On the other hand, capital is seeking to acquire cheap labour either through a highly casualised and migratory labour force or through immobile and home-based workers whose reservation wage is very low. So there is need for effective government policy in the context of labour migration, at least in respect of providing healthy working conditions and social security to the workers.

The paper presents an overview of labour migration in India in the following section. The next section discusses trends and patterns of labour migration by different dimensions. The section following throws light on the different causes of migration and the 
next section analyzes its impacts. The final section concludes.

\section{Labour Migration in India: An Overview}

Migration from one area to another in search of improved livelihoods is a key feature of human nature. While some regions and sectors fall behind in their capacity to support populations, others move ahead and people migrate to access these emerging opportunities. The regional disparity arises due to several reasons. Some of them are natural and some are man-made. It is quite natural that investment would be attracted in developed regions only. Industrialization widens the gap between rural and urban areas, inducing a shift of the workforce towards industrializing areas. There is extensive debate on the factors that cause populations to shift, from those that emphasize individual rationality and household behavior to those that cite the structural logic of capitalist development (de Haan and Rogaly, 2002). Moreover, several studies show that the process of migration is also influenced by social, cultural and economic factors and outcomes can be vastly different for men and women, for different groups and different locations.

The sources of early migration flows were primarily agro-ecological, related to population expansion to new settlements or to conquests (Eaton, 1984). There is considerable information on patterns of migration during the British period. Indian emigration abroad was one consequence of the abolition of slavery and the demand for replacement of labour. This took place through pacts, a form of contract labour whereby a person would bind himself for a specified period of service, usually four to seven years in return for payment of their passage. They left for British, Dutch and French colonies to work in sugar plantations and subsequently for the tea and rubber plantations of Southeast Asia (Tinker, 1974). Similar demands for labour rose internally with the growth of tea, coffee and rubber plantations, coal mines and later, modern industry. But as they settled down, it provided a bridgehead to other migrants, whose numbers grew to satisfy colonial demand. Urban pockets like Kolkata and Mumbai attracted rural labourers mainly from labour catchment areas like Bihar, Uttar Pradesh and Orissa in the east and Andhra Pradesh, Tamil Nadu and parts of Kerala and Karnataka in the south (NCRL, 1991; Joshi and Joshi, 1976; Dasgupta, 1987).
The historical pattern of the flow of labourers persisted even after independence. Between 1951 and 2001, the proportion of the population living in urban areas rose from $17.3 \%$ to $32.8 \%$. Of the total workforce, $73.3 \%$ remained in rural areas. The percentage declined marginally from $77.7 \%$ in 1991 and $79.3 \%$ in 1981 . Given the size of India, the persistence of regional disparities is expected. However the scale and growth of these disparities is of concern. The ratio between the highest to lowest state per capita incomes has increased from 2.6 in 1980-83 to 3.5 in 1997-00 (Srivastava, 2003). The Planning Commission estimates that $26.1 \%$ of India's population lives below the poverty line (based on the National Sample Survey of 1999-2000). The rural poor have gradually concentrated in eastern India and rain fed parts of central and western India. These regions suffer from low-productivity in agriculture.

Earlier studies have shown that poor households participate extensively in migration (Connell et al. 1976). More recent studies have reconfirmed that migration is a significant livelihood strategy for poor households in several regions of India (PRAXIS, 2002; Mosse et al. 2002; Hirway, 2001; Haberfeld et al. 1999; Rogaly et al. 2001; Srivastava, 1998).

\section{Trends and Patterns of Internal Migration by Dimensions}

The two main secondary sources of data on population mobility in India are the Census and the National Sample Survey (NSS). These surveys may underestimate some migration flows, such as temporary, seasonal and circulatory migration, due to empirical and conceptual difficulties. Furthermore, migration data relate to population mobility and not worker mobility. But economic theories of migration are primarily about worker migration. It is not easy to separate these. Firstly, because in both surveys 'migrants' are defined in terms of change from birthplace and change in last usual place of residence. Migrants, according to such definition, are not always employment related. Secondly, migration surveys give only the main reason for migration and that only at the time of migration. Secondary economic reasons could be masked, as in the case of married women, who would cite other reasons for movement. Another 
problem is that migration data relate to stocks of migrants and not to flows.

\section{Population Mobility}

In one view, population mobility in India is low (Davis, 1951; Kundu and Gupta, 1996). In the 1991 census, using the 'change in residence' concept, $27.4 \%$ of the population is considered to have migrated which shows a considerable decline from $30.6 \%$ in 1971 and $31.2 \%$ in 1981 . This is true for male and female migrants. In the case of males, it declined from $18.1 \%$ in 1971 to $14.7 \%$ in 1991 . In the case of females, it declined from $43.1 \%$ in 1971 to $41.6 \%$ in 1991 . However, recent evidence based on NSS figures for 1992-1993 and 1999-2000 and also supported by the census suggests an increase in migration rates - from $24.7 \%$ to $26.6 \%$ in the late $90 \mathrm{~s}$. This evidence also suggests the proportion of migrants of both sexes, in both rural and urban areas, increased during the last decade of the 20th century.

\section{Migration for Work}

The primary motive for migration is an important indicator of how mobility is influenced by conditions of the labour market. Of the $27.4 \%$ who changed place of residence, as per 1991 census, 8.8\% moved for employment reasons and $2.3 \%$ had business motives. The proportion moving due to economic motives was higher for males $(27.8 \%$ moved for employment reasons, and $7.1 \%$ for business reasons) compared with females (only $1.8 \%$ moved for employment reasons and $0.5 \%$ for business reasons).

The proportion migrating for economic reasons is greater among long-distance migrants. Most male migrants moving between states did so for economic reasons. Again, economic motives are more significant in urban migration streams, especially for males. While $49 \%$ of male migrants were in urban areas, $69.2 \%$ of such migrants migrated for employment (Srivastava, 1998). A distinct regional variation emerges in the work pattern of migrants. In the north-eastern states and some others, migrants are mainly employed in the tertiary and secondary sector of the economy. Elsewhere, the primary sector attracts the migrant most.

An analysis of the occupational division of migrant workers (other than cultivators and agricultural labourers) shows that among males, $43 \%$ are engaged in production related work. In the tertiary sector, significant proportions of male migrants are engaged as sales workers, followed by clerical and related work. All the western states have a significant proportion of male migrants in secondary activity and in the southern and north-eastern states they are mainly engaged in the tertiary sector. In the case of female migrant workers, $40 \%$ are in production related works and a significant proportion are in technical and professional activity.

\section{Migration for Work in the 1990s}

Analysis of the recent trends of labour mobility, on the basis of NSS estimates from the $49^{\text {th }}$ (1992-93) and $55^{\text {th }}$ rounds (1999-00) have been carried out by Srivastava and Bhattacharya (2002) and a few central conclusions from that analysis are discussed below. This period shows a sharp increase in urban male mobility, with a significantly larger percentage of male migrants reporting economic and employment linked reasons for mobility. For other streams, there has been a decline in the percentage of migrants giving economic reasons for mobility. A comparison of the decadal migrant streams (migrants who had migrated in the decade preceding the period of survey) shows that (a) a greater percentage of the urban migrant workers were from the nonagricultural sector. They were mostly self-employed or regular employed; (b) a greater percentage of the male migrant workers were self-employed or in regular employment in 1999-00; (c) in the case of females, however, a larger percentage of decadal female migrant workers worked in 1999-00 as casual labourers in the rural areas in agriculture.

Comparing activity status before and after migration for all migrants, they find that migrants in general show much higher work participation rates for both urban and rural areas. In the urban areas the NSS $55^{\text {th }}$ round figures show a significant transition towards regular employment and self-employment among males with a small decline in the percentage of casual labour. In the rural areas, there is an increase in all three categories including casual labour, but the most significant shift is towards self-employment. In the case of female migrants, however, along with an increase in the percentage of workers to population in all three categories after migration, there is also an increase in casualization 
both in rural and urban areas, but quite significantly in the former. These results, along with the decline in short duration migration, which we discuss below, suggest that the 1990s may have provided greater opportunity for labour mobility to those who were better positioned- males in urban areas and in the non-agricultural sector.

\section{Short Duration Labour Migration}

In terms of the duration of migration, Census of India estimates $56.2 \%$ of the migrants in 1991 were of more than 10 years duration, while $21.4 \%$ were of to 9 years duration. Only $3.04 \%$ of the migrants were recorded as short duration ${ }^{3}$. The NSS survey of 1999-00 has estimated that there were 8.64 million short duration in-migrants in 1999-00, out of whom 3.24 million had migrated for economic reasons. However, in 1992-93 the total number of estimated short duration migrants was 16.75 million, suggesting a sharp decline in the subsequent years.

The NSS $55^{\text {th }}$ round has separately estimated ${ }^{4}$ the number of short duration out-migrants ${ }^{5}$ in 1999-00. A total of nearly 10.87 million people stayed away from their UPR (usual place of residence) for work/ seeking work for a period between 2 and 6 months. Of these 8.45 million were resident in rural areas and 2.42 million in urban areas. Among the 8.45 million short duration out-migrant in rural areas, 3.06 million were females and 5.39 million were males.

There were large numbers of migrants in agriculture and plantations, brick kilns, quarries, construction sites and fish processing. A number of field studies over the 1990s also provide rough estimates of the magnitude of seasonal migration in different parts of India. These confirm the considerable scale of such migration. Empirical research on the scale and pattern of seasonal migration of workers to the rice-producing belt of West Bengal carried out in 1999-00 suggests that the number of seasonal migrants moving to Bardhaman district during aman harvesting season exceeds 500,000 and this volume has been growing since the1980s (Rogaly et al. 2001). These migrants are mostly tribals,

\footnotetext{
${ }^{3}$ Short duration migration refers to labor migrating for a period of less than one year.

${ }^{4}$ Such estimate was provided for the first time.

${ }^{5}$ Short duration out-migrants are those who stayed away for a period between 2 and 6 months for work or seeking work.
}

Muslims and persons belonging to other low castes. A study based on annual seasonal migration of tribal households from Khandesh (Dhule district, Maharashtra) to the sugarcane fields of southern Gujarat in 1988-89 estimated that every year 100,000 to 150,000 labourers are recruited from this region to work in the nine sugar co-operatives of Southern Gujarat (Teerink, 1995). Other studies in the tribal areas in MP, Rajasthan and Gujarat also indicate a very high rate of out-migration. In some cases it amounts to whopping $60 \%$ to $80 \%$ of households (Mosse et al. 2002; Haberfeld et al. 1999; Rani and Shylendra, 2001).

A large number of tribals, mainly from drought prone areas of Andhra Pradesh, Karnataka and Maharashtra, migrate to work in construction, tile factory, brick kiln and crop cutting in Maharashtra (Pandey, 1998). Saora, Munda and Santhal tribes have a long history of migration, with only male migration among the Saora (plantation cultivation in Assam and Arunachal Pradesh). Mundas and Santhals migrate as household units, mainly to NALCO site in Denkanal district of Orissa (Menon, 1995). The construction industry mainly depends on migrant labour. $90 \%$ of the labourers are migrants (Vaijanyanta, 1998). Around 40,000 girls migrate from Kerala annually to other state to work in the fishery industry (Sarodamoni, 1995).

The migration statistics borrowed from Census up to the early 1990s shows a near stagnancy. Estimates from NSS also show a marginal decline in population mobility between 1987-88 \& 1993 for overall population. This decline is attributed to the process of economic liberalization which implies the greater movement of capital and natural resources and growing immobility of population as stated by Kundu and Gupta (1996). Nonetheless, a steady increase in internal migration has been witnessed in the post reform era from $24.8 \%$ in 1993 to $28.5 \%$ in 2007-08.

Although overall migration trend is increasing, a significant discrepancy in migration pattern is noticed across gender. There occurs a continuous increase in female migration since 1983 where as a decline in male migration trend except between 1993 \& 1999-00. Such pattern is more pronounced in rural area. It is seen that male migration is declining in rural area from $7.2 \%$ in 1983 to $5.42 \%$ with marginal increase in the periods 1987 and 1999-00. Like rural 
areas, the decline in urban male migration is noticed up to early 1990's; however it has marginally gone up between 1999-00 and 2007-08.

One possibility for decline in male migration could be due to employment generated through National Rural Employment Guarantee Act (NREGA) in village level. It is expected to reduce rural to rural flow which, in turn, influence overall rural male migration. On the other hand, studies show that there occurs fall in rural employment in spite of implementation of NREGA (Chowdhury, 2011). Therefore, another reason for deceleration in male migration can be explained in terms of the jobless growth of Indian economy (de Hann, 2011). Further, a question arises why migration scenario is different in two periods of jobless growth that is 1993-00 (growth rate of employment is less than $1 \%$ ) and 2000-08 (growth rate of employment is $0.17 \%$ ). It is not likely that jobless growth could be the exclusive reason. Rather, it may be one of the reasons. The other possible explanation could be under- estimation of seasonal migration that may influence the overall growth of male migration. Studies by Shylendra and Thomas (1995), NCRL (1991), Srivastava (1998) and Kundu (2003) show that there is under-reporting of internal migration data due to seasonal and circulatory migrants who are concentrated at the lower ends of the labour market spectrum and such type of mobility steadily increases over years (NCRL, 1991, Deshingkar and Farrington, 2009). Given these possibilities, it is difficult to answer the exact possible reason for declining male mobility in present scenario. Unlike male migration a continuous increase in female migration is observed irrespective of place of residence. Although preponderance of female in migration process is largely attributed to marriage, the emerging studies by Shanti (1991), Sundari (2005) and Arya et al. (2006) show that the background reason for female migration is changing from marriage to other reasons, especially to economic ones. Therefore, to explore the reasons for current trends in migration, it is crucial to have a look at the other dimensions of migration followed by distance wise migration.

\section{Migration by Distance}

Migration in India is predominantly short distance, with around $60 \%$ of migrants changing their residence within the district of enumeration and over $20 \%$ within the state of enumeration while the rest move across the state boundaries. A large proportion of women migrate over short distances due to marriage. The proportion of male lifetime migrants is low in most poor states except Madhya Pradesh and high in most developed states. Evidence shows that there is dominance of short distance migration. However, it appears this trend is also slowly changing in the country at least among urban migrants. For 2007-08 in urban area male migration is higher in inter-district (39.31\%) followed by inter-state (31.9\%). Likewise, for female inter-district $(42.51 \%)$ followed by intra-district migration $(38.32 \%)$ dominate the migration flow. A decrease in intra-state mobility accompanied by an increase in inter-district and inter-state mobility is observed irrespective of sex. And the increase is found to be high in inter-state male migration in urban areas from $23.57 \%$ in $1999-00$ to $31.9 \%$ in 2007-08.

The relative increase in inter-state migration is an indication that migration trend is moving towards economic reasons (Singh, 2009). Motivated by better employment opportunities as well as to pursue higher education people migrate to urban areas of developed states. At the same time a growing volume of micro studies shows that people from lower socio-economic strata of under developed states migrated to developed states in pursuit of getting employment. Such migration was induced by poverty, inequality and other environmental vulnerabilities.

Around half of the migration flow is rural to rural in 2007-08. Around $1 / 4$ th of migrants constitute rural to urban followed by urban-urban and urban to rural. However, there occurs a wide gender difference in migration flow. It is seen that for female rural to rural constitute $60 \%$ of migration flow which is less than $30 \%$ for male. On the contrary $34 \%$ of male migrated from rural to urban which is less than $20 \%$ for female.

It is expected that with generation of employment opportunities in urban areas, migration from rural areas continuously increases. The latest NSS estimates show that $56 \%$ migration in the rural to urban flow is due to employment and there occurs an increase in salaried/wage earning class over the period from $28 \%$ in $1999-00$ to $32 \%$ in $2007-08$ 
which is declining in other types of employment. In this regard studies by Shylendra, et al. (1995), de Hann (1997) and Srivastava and Bhattacharya (2002) show that the increasing rural to urban migration in recent years is largely due to economic reasons as they are mostly motivated by availability of urban employment in the expanding informal sector. Some development analysts like Kundu (2011) hold that the structural reform adopted in the country since the early 1990s has opened up job opportunities in several globally linked sectors located in and around the cities, boosting rural-urban migration.

Like India, the other South Asian and South East Asian countries experiencing rural to urban migration in response to alternation in the structure of economy that creates regular and remunerative wage work in urban areas leads to high degree of spatial mobility (Gazdar, 2003, ADB, 2001, Acharya, 2003, Ping, 2003, Afsar, 2003, Thanh et al. 2005). On the contrary, studies by (Kundu, 1997 and Mitra et al. 2008) argue that adverse impact of economic reform, slow growth in agriculture, poverty, unemployment etc increases rural to urban migration. Along with poverty and unemployment other factors like environmental degradation and low impact of anti-poverty programme in providing employment results in labour migration to urban areas (NCRL, 1991). Besides economic factor, non-economic factors like education, changes in administrative boundaries also influence rural to urban migration (Singh et al. 1998; James, 2002 and Singh, 2009).

Studies show that interstate mobility is generally low in the states with high level of poverty, illiteracy etc. (Kadi et al. 1988). However, in recent years there is an increasing outflow of people from backward states reflecting migration of unskilled and low educated people. It is found that net migration rate is positive in developed states like Maharashtra, Gujarat, Karnataka, Haryana and Punjab indicating inflow of people to these states. This can be explained in terms of industrialization, availability of employment and social development of the states. On the contrary due to large concentration of population, inequality and poverty etc. states like Uttar Pradesh, Bihar, Madhya Pradesh, Orissa and Rajasthan and north-eastern states supplies large number of migrants to economically developed state like Maharashtra, Gujarat, Punjab and Delhi.
The village level studies carried out by (Rao, 2001; Deshingkar et al. 2003, Karan, 2003, Dayal and Karan, 2003, Action Aid, 2005) shows high level of out-migration from poor and drought prone areas of backward states like Andhra Pradesh, Orissa, Bihar, Jharkhand, Rajasthan and Madhya Pradesh to developed states due to opportunities in informal economy. On the contrary, studies by (Oberai and Singh, 1983; Skeldon, 2002; Bhagat, 2009) state that with the increasing level of development of the state the migration rates both (in and out) increase.

\section{CAUSES OF MIGRATION}

Given the diversity in the nature of migration in India, the causes are also bound to vary. Migration is influenced both by the pattern of development (NCRL, 1991) and the social structure (Mosse et al. 2002). The National Commission on Rural Labour, focusing on seasonal migration, concluded that uneven development was the main cause of seasonal migration. Along with interregional disparity, disparity between different socio-economic classes and the development policy adopted since independence has accelerated the process of seasonal migration. Most migration literature makes a distinction between 'pull' and 'push' factors, which do not operate in isolation of one another. Mobility occurs when workers in source areas lack suitable options for employment/livelihood, and there is some expectation of improvement in circumstances through migration. The improvement sought may be better employment or higher wages/incomes, but also maximization of family employment or smoothing of employment/income/consumption over the year. This is referred to as the 'pull' factor causing individuals to migrate. At one end of the migration spectrum, workers could be locked into a debt-migration cycle, where earnings from migration are used to repay debts incurred at home or in the destination areas, thereby cementing the migration cycle. This is referred to as the 'push' factor in the literature. At the other end, migration is largely voluntary, although shaped by their limited choices.

The NCRL has recognized the existence of this continuum for poor migrants by distinguishing between rural labour migration for survival and for subsistence. The landless poor, who mostly belong to lower caste, indigenous communities, 
from economically backward regions, migrate for survival and constitute a significant proportion of seasonal labour flow (Study Group on Migrant Labour, 1990). The growth of intensive agriculture and commercialization of agriculture since the late 1960s has led to peak periods of labour demand, often also coinciding with a decline in local labour deployment. In the case of labour flows to the rice producing belt of West Bengal, wage differentials between the source and destination have been considered as the main reason for migration. Moreover, absence of non-farm employment, low agricultural production has resulted in a growth of seasonal migration (Rogaly et al. 2001). Factors such as age, education level, wealth, land-owned, productivity and job opportunities influence the participation of individuals and households in migration, but so do social attitudes and supporting social networks (Haberfeld et al. 1999; Rogaly et al. 2001; Mosse et al. 2002).

In Dhule region (Maharashtra) sugarcane cultivation leads to high demand for labour, but landowners recruit labourers from other districts for harvesting as they can have effective control over the labour. Local labourers are thus forced to migrate with their households to South Gujarat (Teerink 1995). In Kerala, trawler-fishing has depleted marine resources. With unemployment in other industries like cashew and rubber, this has led to large scale out-migration of girls (Sardamoni, 1995).

\section{THE IMPACT OF MIGRATION}

\section{On Migrants and their Families}

Poorer migrant workers have few entitlements vis a vis their employers or the public authorities in the destination areas. They have meager personal assets and suffer from deprivations in the destination areas. In the source areas, migration has both negative and positive consequences for migrants and their families. Although migration gives higher wage/salary to migrants, difference in living standard and adverse impacts on health, education and family members would have a depressing effect on migrant's well-being. So the conclusion is, in some sense, ambiguous.

\section{On Living Conditions}

Migrant labourers, whether agricultural or non- agricultural, live in terrible conditions. There is no provision of safe drinking water or hygienic sanitation. Most live in open spaces or makeshift shelters in spite of the Contract Labour Act which stipulates that the contractor or employer should provide suitable accommodation (NCRL, 1991; GVT, 2002; Rani and Shylendra, 2001). Apart from seasonal workers, workers who migrate to the cities for job live in parks and pavements. Slum dwellers, who are mostly migrants, stay in deplorable conditions, with inadequate water and bad drainage. Food costs more for migrant workers who are not able to obtain temporary ration cards.

\section{On Health and Education}

Labourers working in harsh circumstances and living in unhygienic conditions suffer from serious occupational health problems and are vulnerable to disease. Those working in quarries, construction sites and mines suffer from various health hazards, mostly lung diseases. As the employer does not follow safety measures, accidents are quite frequent. Migrants cannot access various health and family care programmes due to their temporary status. Free public health care facilities and programmes are not accessible to them. For women workers, there is no provision of maternity leave, forcing them to resume work almost immediately after child birth. Workers, particularly those working in tile factories and brick kilns suffer from occupational health hazards such as body ache, sunstroke and skin irritation (NCRL, 1991). As there are no nursery school facilities, children often accompany their families to the workplace to be exposed to health hazards.

They are also deprived of education: the schooling system at home does not take into account their migration pattern and their temporary status in the destination areas does not make them eligible for schooling there (Rogaly et al. 2001; 2002). In the case of male-only migration, the absence of men adds to material and psychological insecurity, leading to pressures and negotiations with wider family (Rogaly et al. 2001; 2002). Male out-migration has been seen to influence the participation of women in the directly productive sphere of the economy as workers and decision-makers and increase the level of their interaction with the outside world (Srivastava, 1999). But given the patriarchal set up, women may have to cope with a number of problems 
which are exacerbated due to the uncertainty of the timing and magnitude of remittances on which the precarious household economy depends. This, in turn, pushes women and children from poor labouring households to participate in the labour market under adverse conditions. Thus, the impact of migration on the women can be two-sided but the strong influence of patriarchy restricts the scope of women's autonomy (Teerink, 1995; Menon, 1995; Rogaly et al. 2001). The impact of male migration can be especially adverse for girls, who often have to bear additional domestic responsibilities and take care of younger siblings. The absence of male supervision further reduces their chances of acquiring education (Srivastava, 2001).

There are several cases where women participate in the migration streams along with male members of their households. It is usual in such cases for younger siblings and older children to accompany their parents and to work along with them. Family migration usually implies migration of the younger members of the family, leaving the elderly to cope with additional responsibilities while at the same time fend for their subsistence and other basic requirements (Mosse et al. 1997).

\section{On Source Areas}

The major impacts of migration on source areas occur through changes in the labour market, income and assets, changes in the pattern of expenditure and investment. Although seasonal outmigration potentially has the effect of smoothing out employment over the annual cycle, rural outmigration could cause a tightening of the labour market in some circumstances. However, empirical evidence from out-migrant areas does not often attest to this (Connell et al. 1976; Srivastava, 1999). This may be because out-migration often takes place in labour surplus situations. There is also evidence of the replacement of out-migrant male labour by female and even child labour.

\section{On Remittances and Effect on Sending Areas}

While the impact of out-migration via the labour market has been reviewed above, the other source of changes which need to be analyzed would work through changes in income, income distribution and the pattern of expenditure and investment. Although we do not have direct evidence of the value of remittances from migrants, some indirect evidence can be adduced from the NSS surveys on migration and consumption and employment/unemployment. These surveys give the percentage of out-migrants making remittances and households receiving remittances and depending upon remittances as their major source of livelihood. In 1992-93, $89 \%$ of permanent out-migrants sent remittances. The percentage of all rural households receiving remittance income is also fairly high - in some regions of the country, one-quarter to one-third of the households receive remittances. It should be noted that remittances are only one form in which resource flows occur as a result of migration, the other being savings brought home by migrants in cash or kind. Field studies show that a majority of seasonal migrants either remit or bring home savings. In many cases, a substantial proportion of household cash income is attributed to migrant earnings (Haberfeld et al. 1999; Rogaly et al. 2001; Mosse et al. 2002). However, the cash incomes which accrue may not always add to the resource base of migrant households as some are used to adjust earlier debts (NCRL, 1991; Mosse et al. 2002).

However, it does appear that the income and consumption level of migrant households is generally higher than that of similarly placed non-migrants (Sharma, 1997; Krishnaiah, 1997). As Mosse et al. (2002) have noted, and as other studies testify, migrants are not only differentially placed at the entry point, their differential status also leads to different trajectories, so that changes in post-migration average incomes may provide only a limited picture of the varied setoff changes. (Rogaly et al. 2001) provides some evidence of improvement in incomes of seasonal migrants as a result of migration, but these conclusions need to be supported by other studies. The impact of migration on income and asset inequality is limited. The ethnographical study quoted above (Rogaly et al. 2001), finds evidence of reduced inequality, as incomes of labour households rise against nonlabour households. In another context, Mosse et al. (1997) suggest that these inequalities increase because the differentiated nature of the migration process led to the amplification of income and asset inequalities.

Remittances are mainly used for purposes like consumption, repayment of loans and meeting 
other social obligations. These constitute, in effect the 'first charge' on migrant incomes. The evidence on investment is, however, mixed. Investment by migrant households on housing, land and consumer durables is common and migrant income is also used to finance working capital requirements in agriculture. Evidence of other productive farm or non-farm investment is scarce but a number of studies do report such investment by a small percentage of migrant and return migrant households (Oberai and Singh, 1983; Krishnaiah, 1997; Sharma, 1997; Rogaly et al. 2001).

A major linked issue is the role of rural outmigration in the material and social reproduction of rural households and the extant relationships in which they are placed. Standing (1985) has argued that circulatory migration in particular contributes to the stability of rural production relations. He argues that circulatory labour migrations has 'safety valve' features and 'has often been a mechanism preserving a social mode of production or at least reducing the pressures on it'. Temporary migration may allow households to relieve underemployment and meet debt and other obligations without having to sell assets. 'Relay migration' can also be seen as a part of the household survival strategy. Indeed the long history of rural out-migration in some of the source areas in India combined with agricultural and rural stagnation seems to confirm the stabilizing role of out-migration. But labour circulation as well as other forms of rural outmigration can also disrupt pre-existing production relations. The major impact on source areas appears to be through the labour market, with recent evidence indicating greater mobility of rural labour households leading to a less isolated and more generalized agriculture labour market and an upward pressure on wages. Further there is also evidence of some impact through improvement in the resource base of the migrant households (Srivastava, 1998).

\section{On Destination Areas}

There are clearly multiple rationales for the use of migrant labour in destination areas. While shortages of local labour provides one important rationale (Singh and Iyer, 1985; Oberai and Singh, 1983), virtually all available evidence shows that recruitment of immigrants is as much motivated by strategies of labour control and wage cost reduction.
Numerous cases have been documented where the same areas export and import labour to identical sectors. Migrants are preferred because their labour is easier to control and it is easier to extract labour from them under difficult conditions. Moreover, the supply of labour can be easily increased or decreased with little cost to employers and migrants can work for long and flexible hours. Flexibility of the migrant workforce is reinforced because of the role of contractors and middlemen in recruitment and supervision. The segmentation of the labour market, which also leads to greater control over both migrant and local labour, is another outcome of the process. Finally, the wage payment systems which grow around industries based predominantly on migrant labour are eminently suited to sidestepping minimum wage legislation. Thus migration reduces labour cost to employers.

The labour market outcomes generated by labour immigration facilitate a certain kind of growth and accumulation in the destination areas, although this is via what can be described as a 'low road' to capitalism. According to Breman (1996) the basic rationale for the growing informalization, two-way mobility of labour and segmentation is to be found in the type of mercantilist capitalist development witnessed in India, just as international migration is strongly related to the structure of international capitalism (Sassen, 1988; Piore, 1990). Capitalists operate in uncertain markets, under circumstances in which they are highly dependent on traders. Labour immigration is one of the strategies favored by entrepreneurs to shift both risk and cost of production on to workers. Another reason for continued informalization is to keep businesses away from state surveillance. Thus most enterprises in the informal sector escape regulation of any kind. Furthermore, in such destination areas, employers rarely provide anything other than wage subsistence requirements. Migrant labourers have to fend for themselves to meet their health, shelter and other basic requirements. Although the poor condition in which labourers subsist is a result of employers not internalizing the legitimate costs of hiring labour (contravening numerous laws), to society the resulting urban congestion appears to be result of unplanned mobility. The costs of population mobility have been, as a result, considered in theory in the context of large costs imposed by 
population concentration in large cities. The social, political and other consequences of immigration, especially where such migration is by linguistically, ethnically or regionally distinct groups, has not been considered in the growing economic literature on internal migration, but figures prominently in the body of sociological and political literature (Weiner, 1978).

\section{CONCLUSION}

The paper takes up an important socio-economic and political issue - labour migration. This issue is somewhat neglected in the economic literature in the sense that there are many areas which remain unexplored as compared to other socio-economiccultural and political issues. Hence the paper attempts to present in a nutshell trends of labour migration in India, its causes and impacts. We feel that it would be of great help to the researchers in conducting research in the areas left unexplored by the literature.

Between 1971 and 1991, the migration rate has declined both for male and female. But we find an increase in such rate in the last decade of 90s. The reason for such trend is the rapid development and expansion of the informal sector which absorbed a large number of workers from the rural areas. This implies labourers were casualized. The rate of male migration for work has declined since the 90s and the corresponding rate has gone up for females. The reason behind such phenomenon is the introduction and implementation of NREGA in different states. In terms of duration, short duration in-migration exhibits a declining trend. The out-migrants migrating for short duration were mostly from rural areas and majority of them were males. Lastly, the trend analysis shows that a high proportion of male migrate over a long distance and they are rural to urban in nature. On the contrary, females generally migrate over a short distance and it is rural to rural in nature. The reason behind such short distance migration has been marriage.

The paper observes that uneven development has been the predominant driving force behind labour migration. Besides, disparities in socio-economic conditions, wage differentials and disparities in the development policies also induce individuals to migrate. Moreover, two factors, identified as 'push' and 'pull' factors, operate either simultaneously or in isolation to generate migration flow. If an individual migrate to attain improved standard of living by getting high wage/salary then it is called migration due to 'pull' factor. On the other hand, individuals often migrate to repay the old debt at source area, which is called 'push' factor.

Finally, the paper discusses the probable impact of labour migration on the migrant, his/her family members and on the source and destination areas. We conclude that migration has miserable impact on the living standard of migrants, their family members and they are deprived of health, education and other essential public services and basic amenities like hygiene, drinking water and so on. The remittances sent by the migrant back home is often used to repay outstanding debts and support increased consumption.

\section{REFERENCES}

Acharya, S. 2003. 'Migration Patterns in Cambodia-causes and consequences', Ad hoc expert group meeting on Migration and Development, 27-29 August, Bangkok.

Action Aid 2005. 'From Hunger to Suffering ... a Journey: Migrant Workers in the Brick Kilns' - Interventions Report. Hyderabad Action Aid.

Afsar, R. 2003. 'Dynamics of poverty, development and population mobility: the Bangladesh case', Adhoc Expert group meeting on migration and Development, organized by the Economic and Social Commission for Asia and the Pacific, Bangkok, 27-29 August.

Arya. S. and Roy, A. 2006. "Poverty, Gender and Migration", Sage Publication.

Bhagat, R.B. 2009. 'Internal Migration in India: Are the Underclass More Mobile?' Paper presented in the $26^{\text {th }}$ IUSSP General Population Conference held in Marrakech, Morocco, 27 September- 2 October 2009.

Breman, J. 1996. “Footloose Labour: Working in India's Informal Sector", Cambridge: Cambridge University Press.

Chowdhury, S. 2011. 'Employment in India: What does the latest data show', Economic and Political Weekly, XLVI(32).

Connell, J., Dasgupta, B., Laishley, R. and Lipton, M. 1976. "Migration from Rural Areas: The Evidence from Village Studies", Delhi: Oxford University Press.

Dasgupta, B. 1987. "Issues of migration and employment with reference to Calcutta", in: Davis, K. (1951): “The Population of India and Pakistan", New Jersey: Princeton University Press.

Dayal, H. and Karan, A.K. 2003. 'Labour Migration from Jharkhand', Institute for Human Development, New Delhi.

de Haan, A. 1997. 'Rural-urban migration and poverty: the case of India', IDS Bulletin, 28(2): 35-47. 
de Haan, A. and Rogaly, B. 2002. "Introduction: Migrant workers and their role in rural change", Journal of Development Studies, 37(5).

de Hann, A. 2011. 'Inclusive growth? Labour migration and poverty in India', Working Paper No.513, International Institute of Social Studies.

Deshingkar, P. and Start, D. 2003. 'Seasonal Migration for livelihoods, coping, accumulation and exclusion', Working Paper No. 220, Overseas Development Institute, London.

Deshingkar, P. and Farrington, J. 2009. 'Circular Migration and Multi locational Livelihood Strategies in Rural India', Oxford University Press, New Delhi.

Eaton, R. 1984. “The Rise of Islam and Bengal Frontier", Delhi: Oxford University Press.

Gazdar, H. 2003. 'A Review of Migration Issues in Pakistan', paper presented at the Regional Conference on Migration, Development and Pro-Poor Policy Choices in Asia, Organized by Bangaladesh Refuges Migratory Movements Research Unit, Bangladesh/DFID UK, Dhaka, 22-24 June.

Gramin Vikas Trust 2002. “Migration: An Essential Component of Rural Livelihoods", Ratlam, India: Gramin Vikas Trust.

Haberfeld, Y., Menaria, R.K., Sahoo, B.B. and Vyas, R.N. 1999. "Seasonal migration of rural labour in India". Population Research and Policy Review, 18(6): 471-87.

Harris, J.R. and Todaro, M.P. 1970. “Migration, unemployment and development: A two sector analysis", American Economic Review, 60(1): 126-38.

Hirway, I. 2001. "How Far Can Poverty Alleviation Programmes Go? An Assessment of PAPs in Gujarat", Ahmedabad, India: Centre for Development Alternatives.

James, K. 2002. 'Migration dynamics in Andhra Pradesh: Evidence from Decadal Census', Paper presented in a seminar on Labour Mobility in a Globalising World: Conceptual and empirical issues.

Joshi, V. and Joshi, H. 1976. "Surplus Labour and the City: A Study of Bombay", Delhi: Oxford University Press.

Kadi, A.S. and Sivamurthy, M. 1988. 'Interstate Migration in India: 1971-81', Canadian Studies in Population, 15(1): 37-50.

Karan, A. 2003. 'Changing Patterns of Migration from Rural Bihar', in G. Iyer (eds) Migrant Labour and Human Rights in India, New Delhi: Kanishka Publishers, pp. 102-39.

Krishnaiah, M. 1997. "Rural migrant labour systems in semiarid areas: A study of two villages in Andhra Pradesh", The Indian Journal of Labour Economics, 40(1).

Kundu, A. 1997. 'Trends and Structure of Employment in the 1990s: Implication for Urban.

Kundu, A. 2003. 'Urbanisation and urban governance, search for a perspective beyond neoliberalism,' Economic and Political Weekly, XXXVIII(29): 3079-98.

Kundu, A. and Gupta, S. 1996. "Migration, urbanisation and regional inequality". Economic and Political Weekly, December 28, pp. 3391-98.

Kundu, A. 2011. "Trends and Processes of Urbanisation in India", Urbanization and emerging population issues.
Lewis, A. 1954. "Economic development with unlimited supplies of labour", Manchester School of Economic and Social Studies, May.

Menon, G. 1995. “The impact of migration on the work and status of tribal women in Orissa", in: Schenk-Sandbergen, L. ed. (1995) Women and Seasonal Labour Migration. IndoDutch Series on Development Alternatives 16. New Delhi: Sage Publications.

Mitra, A. and Murayama, M. 2008. 'Rural to Urban Migration: A District Level Analysis for India', IDE discussion paper no.137.

Mosse, D., Gupta, S., Mehta, M., Shah, V. and Rees, J. 1997. "Seasonal Labour Migration in Tribal (Bhil) Western India", Swansea: Centre for Development Studies, University of Wales.

Mosse, D., Gupta, S., Mehta, M., Shah, V., Rees, J. and KRIBP Team 2002. "Brokered livelihoods: Debt, labour migration and development in tribal western India", Journal of Development Studies, 38(5): 59-88.

National Commission on Rural Labour 1991. 'Reports of the Study Group on Migrant Labour', Vol. II, GOI, Ministry of Labour, New Delhi.

Oberai, A.S. and Singh, M.H.K. 1983. "Causes and Consequences of Internal Migration: A Study in the Indian Punjab", Delhi: Oxford University Press.

Pandey, D. 1998. "Migrant labour, employment and gender dimension", Indian Journal of Social Work, 59(3).

Ping, H. 2003. 'China Migration country study', Paper presented at the regional Conference on Migration, Development and Pro-Poor Policy Choices in Asia, organized by the Bangladesh Refugee and Migratory Movement Research Unit, Bangladesh/DFID UK, Dhaka, 22-24 June.

Piore, M.J. 1990. “Birds of Passage: Migrant Labour and Industrial Societies", Cambridge: Cambridge University Press.

PRAXIS (Institute for Participatory Practices) 2002. “MP Participatory Poverty Assessment", Report prepared for ADB.

Rani, U. and Shylendra, H.S. 2001. "Seasonal migration and rural-urban interface in semi-arid tropics of Gujarat: Study of a tribal village", Journal of Rural Development, 20: 187-217.

Rao, G.B. 2001. 'Household coping/survival strategies in drought prone regions: a case study of Anantapur District, Andhra Pradesh', Indian Society for Promotion of wastelands Development, New Delhi.

Rogaly, B., Daniel, C., Rafique, A., Rana, K., Sengupta, A. and Biswas, J. 2002. "Seasonal migration and welfare/illfare in eastern India: A social analysis", Journal of Development Studies, 38(5).

Rogaly, B., Biswas, J., Coppard, D., Rafique, A., Rana, K. and Sengupta, A. 2001. "Seasonal migration, social change and migrants rights, lessons from West Bengal", Economic and Political Weekly, pp. 4547-58. 
Sardamoni, K. 1995. "Crisis in the fishing industry and women's migration: The case of Kerala", in: SchenkSandbergen, L. ed. (1995) Women and Seasonal Labour Migration, Indo-Dutch Series on Development Alternatives 16. New Delhi: Sage Publications.

Sassen, S. 1988. "The Mobility of Labour and Capital: A Study in International Investment and Labour Flow", Cambridge: Cambridge University Press.

Shanti, K. 1991. 'Issues relating to economic migration of females', The Indian Journal of Labour Economics, 34(4).

Sharma, A.N. 1997. "People on the Move: Nature and Implications of Migration in a Backward Economy", Delhi: Vikas.

Shylendra, H.S. and Thomas, P. 1995. 'Non-Farm Employment: nature, magnitude and determinants in a semi-arid village of Western India', Indian Journal of Agricultural Economics, 50(3): 410-416.

Singh, D.P. 2009. 'Poverty and migration: does Moving Help?' in Kundu A. (eds), India: Urban Poverty Report 2009, New Delhi, Oxford University Press.

Singh, M. and Iyer, K.G. 1985. "Migrant labourers in rural Punjab", in: Patnaik, U. and Dingwaney, M. eds. (1985) Chains of Servitude: Bondage and Slavery in India. Delhi: Sangam Books.

Singh, S.P. and Aggarwal, R.K. 1998. 'Rural-Urban Migration: The Role of Push and Pull factors revisited', The Indian Journal of Labour Economics, 41(4): 653-667.

Skeldon, R. 2002. 'Migration and Poverty', Asia-Pacific Population Journal, 17(4): 67-82.

Srivastava, R.S. 1998. "Migration and the labour market in India", Indian Journal of Labour Economics, 41(4).

Srivastava, R.S. 1999. "Rural labour in Uttar Pradesh: Emerging features of subsistence, contradiction and resistance", Journal of Peasant Studies, 26(2 and 3).

Srivastava, R.S. 2001. "Access to basic education in Uttar Pradesh", in: Vaidyanathan, A. and Gopinathan Nair, P.R. eds. (2001) Elementary Education in Rural India: A Grassroots View. New Delhi: Sage Publications.
Srivastava, R.S. 2003. "Regional growth and disparities", in: Alternative Survey Group eds. (2003) Alternative Economic Survey 2001-2, Economic Reform: Development Denied. New Delhi: Rainbow Publishers.

Srivastava, R.S. and Bhattacharyya, S. 2002. "Globalisation, Reforms and Internal Labour Mobility: Analysis of Recent Indian Trends", Paper presented at a seminar 'Labour Mobility and Globalising World: Conceptual and Empirical Issues'. September 18-19 2002, V.V. Giri National Labour Institute, ISLE and IHD.

Standing, G. 1985. "Circulation and the labour process", in: Standing, G. ed. (1985) Labour Circulation and the Labour Process. London: Croom Helm.

Sundari, S. 2005. 'Migration as a Livelihood Strategy: A Gender perspective', Economic and Political Weekly, May 28-June 4.

Teerink, R. 1995. "Migration and its impact on Kandhesi women in the sugarcane harvest", in: Schenk-Sandbergen, L. ed. (1995) Women and Seasonal Labour Migration, IndoDutch Series on Development Alternatives 16. New Delhi: Sage Publications.

Thanh, H.X., Anh, D.N. and Tacoli, C. 2005. 'Livelihood diversification and rural-urban linkages in Viet Nam's red River Delta', mimeo report, November.

Tinker, H. 1974. "A New System of Slavery: The Export of Indian Labour Overseas 1830-1920", London: Oxford University Press.

Vaijanyanta, A. 1998. "Advocating for the rights of construction workers: Nirman's experience", Indian Journal of Social Work, 59(3).

Weiner, M. 1978. "Sons of the Soil: Migration and Ethnic Conflict in India", New Jersey: Princeton University Press. 
